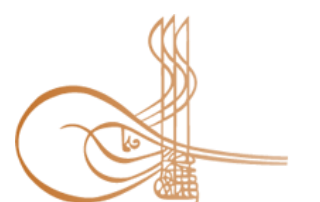

www.turkishstudies.net/economy
Turkish Studies - Economics, Finance, Politics

eISSN: 2667-5625

Research Article / Araștırma Makalesi

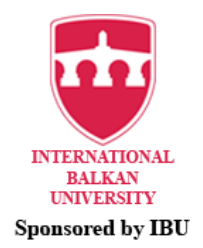

Sponsored by IBU

\title{
Tarım Politikaları Bağlamında İşgücü Piyasalarında Yapısal Dönüşüm ve Kadın İşgücünün Yeniden Şekillenmesi: Muğla Tütüncülük Faaliyetleri Örneği
}

\author{
Structural Transformation in Labor Markets in the Context of Agricultural Policies and \\ Restructuring of Women Labor Force: The Case of Tobacco Growing Activities in Muğla
}

\author{
Gülay Örmeci Güney*- Aslı Karataş** - Kurtuluş Bozkurt***
}

\begin{abstract}
Within the economic activities, the agricultural sector has a separate importance structurally. The agricultural sector, which maintains its indispensability among basic production activities, also affects the agricultural policies applied in this field and the labor markets. Economic and social structure changes in today's world of women in the labour market has been more concerned to take part. Women's participation in economic and social life is the most important indicators of what proportion of women are employed. In terms of sectoral distribution of working women still intensity despite being employed in the agricultural sector, this figure was found to have changed in recent years. In the agricultural sector in parallel with the changes in women's employment in the services sector was the change in rates of women employed.

The main purpose of the study is; analyzing the effects of changes in agricultural policies on the labor markets in the context of women in the labor markets and tobacco growing activities. At this point, Mentese district of Muğla, which was a major tobacco-center and one of the most affected regions by agricultural policy changes, constitutes the sample of the study. In this context, women who were involved in tobacco-related activities from the important tobacco production centers of Menteşe region, Düğerek, Kötekli and Yerkesik, were contacted and interviewed in-depth. As a result of in-depth interviews with these women; It is seen that the structural changes and privatization in the agricultural sector and the radical changes in the agricultural support policies adversely affected the employees in agriculture.
\end{abstract}

Structured Abstract: Agricultural life that started in the Neolithic period played a major role in the survival of mankind. From the Neolithic era, when plant and animal domestication emerged, that is roughly 10,000 years ago, all humans were hunter-gatherers. With the Industrial Revolution, traditional forms of agriculture

\footnotetext{
* Dr. Öğr. Üyesi, Muğla Sttkı Koçman Üniversitesi, Muğla Meslek Yüksek Okulu Asst. Prof. Dr., Mugla Sitkı Koçman University, Muğla Vocational School

ORCID 0000-0002-0398-6640

gulayormeciguney@gmail.com

*** Dr. Öğr. Üyesi, Muğla Sitkı Koçman Üniversitesi, Muğla Meslek Yüksek Okulu

Asst. Prof. Dr., Mugla Sttkı Koçman University, Muğla Vocational School

ORCID 0000-0002-0124-2007

aslikaratas@mu.edu.tr

**** Doç. Dr., Aydın Adnan Menderes Üniversitesi, Söke İşletme Fakültesi, Ekonomi Bölümü

Associate Prof., Aydın Adnan Menderes University, Söke Faculty of Management, Department of Economics

ORCID 0000-0002-9098-9208

kurtulusbozkurt@adu.edu.tr

Cite as/ Atıf: Örmeci Güney, G., Karataş, A. \& Bozkurt K. (2020). Tarım politikaları bağlamında işgücü piyasalarında yapısal dönüşüm ve kadın işgücünün yeniden şekillenmesi: Muğla tütüncülük faaliyetleri örneği. Turkish Studies Economy, 15(3), 1539-1555. https://dx.doi.org/10.47644/TurkishStudies.40450

Received/Geliş: 07 January/Ocak 2020

Accepted/Kabul: 20 September/Eylül 2020

Copyright $\subset$ INTAC LTD, Turkey
} 
quickly vanished within two hundred years and were stuck in their narrow spaces, just like hunter-gatherers, drawn to the borders of the world. It was replaced by machine based-farming and the traditional production unit which are the villages with the small towns that they fed, are converted to metropolises where industry was concentrated. There has been a large population increase and the proportion of the population living on agriculture has decreased gradually (Aydın \& Erdal, 2018: 119).

The change and transformation experienced with globalization has also had a direct impact on the markets. The economic policies put into practice in international platforms have brought the restructuring processes in the sectoral sense through the revised policies both in the national and regional framework. The agricultural sector is among the most affected by these structuring programs. These changes, both visible in the context of production and consumption, have brought new constraints to the labor force who are already struggling in the agricultural sector.

These developments experienced in the agricultural sector on a global scale in this regard, has affected Turkey both in the macro and micro dimensions. Tobacco and tobacco-located activities in the Turkish Agricultural Sector have received its share from the affected distribution of employment and the reflections of global policies has changed the structure of employment in the Turkish agricultural sector. In this study, in the light of all these developments, the changes in the employment structure in Turkish Agriculture Sector, how tobacco activities and female labor force were affected by these changes were investigated.

The main purpose of the study is not only to examine prominent results or dominant findings, but also to reveal the causal forces of objects and relationships and to identify implicit elements. For this reason, indepth interview technique was preferred as a research method. One of the most significant advantages of the in-depth interview technique, which is highly effective in sharing ideas, problems and solution proposals of individuals involved in the research subject or interaction groups, is to make it easy to reach different and new findings. As Kitzinger (1995) states, this technique is frequently used in social sciences and is one of the most systematic data collection methods. The use of quantitative techniques as a supportive method in order to reveal the realities below the visible, especially in social sciences, and based on qualitative techniques in explaining social realities enables more productive results.

The main population of the research is the women labor force in the tobacco sector in Muğla. The working group of the research is active women in the tobacco sector in Muğla province. A total of 32 questions, prepared in accordance with the in-depth interview techniques, were asked to determine the effects on women's labor force that occurred via the structural transformation in the labor market in terms of agricultural policies. 9 of the questions were demographic and 23 were open-ended questions.

Some of the results obtained are:

- It has been determined that women who used to work in tobacco growing in the past, were either eliminated from working life today or continued to work as unpaid family worker in the agricultural sector or shifted to other sectors as unregistered worker or employed in other sectors, especially in the service sector.

- Since the tobacco sector is no longer an important source of income and even the tobacco producers in Muğla are almost non-existent, the women interviewed were asked about the differences between the period they worked in tobacco and their present situation and the e impact of this transformation on their lives. As a result of the answers given, it was understood that there was a serious loss of income and consequently the impoverishment increased. In other words, when the standards of life of the women who previously worked in tobacco were examined, it was found that they experienced a decrease in their welfare levels.

- Women, previously employed in tobacco were asked questions to compare their working conditions and durations to compare during tobacco and after tobacco. As a result of the answers received; It was observed that there were differences in working conditions between the period they worked in the tobacco sector and the following period, some of them had more reasonable working conditions, some the opposite.

As a result, some of the problems in the agricultural sector have shown itself in the tobacco sector, which is a sub-activity in the agricultural sector. Especially in the framework of neo-liberal economic policies, tobacco production, which was high in the province of Muğla until the early 1990s, declined within the scope of the agricultural policies and programs implemented (as a result of the quota implementation, monopoly closure, privatization, and the guarantee conversion). 
Tobacco producers and tobacco production were adversely affected by the quota application started with the decision of the Council of Ministers in 1993 and with the introduction of contracted production in 2002. Moreover, low-bid price policies and economic crises in our country were effective in the formation of this negative picture. As a result of this, the tobacco sector lost its appeal, lost value and tobacco activities gradually decreased. Naturally, those employed in this sector were affected by this negative picture and as a result of these changes, the structure of the labor market was transformed in the context of transition between sectors.

At this point in the agricultural sector and tobacco, the changes in the support policies in the agricultural sector and the negative changes in the future expectations of the producers have had a negative effect. Current status of agricultural production owners confirmed the existence of a workforce that turned into a standard work force from owning the facilities and producing tobacco products.

At the point reached today, it can be said that the leading variables behind this negative picture in the tobacco activities, are the programs implemented in the agricultural sector in the context of agricultural policies.

Keywords: Economics, Macroeconomics, Labor Market, Tabacco Market, Women Labor.

Öz: Ekonomik faaliyetler içerisinde tarım sektörü yapısal olarak ayrı bir önem taşımaktadır. Temel üretim faaliyetleri içerisinde vazgeçilmezliğini koruyan tarım sektörü, bu alanda uygulanan tarımsal politikalar ile işgücü piyasalarını da etkilemektedir. Ekonomik ve sosyal yapının değiştiği günümüz dünyasında kadınların işgücü piyasasında daha fazla yer alması söz konusu olmuştur. Kadınların ekonomik ve sosyal yaşama katılımları konusundaki en önemli gösterge ise kadınların ne oranda istihdam edildiğidir. Sektörel dağılım açısından çalışan kadınların hala yoğunlukla tarım sektöründe istihdam edilmelerine rağmen, bu oranın son yıllarda değiştiği saptanmıştır. Tarım sektöründe kadın istihdamında yaşanan değişimlere paralel olarak hizmetler sektöründe istihdam edilen kadınların oranlarında da değişim gerçekleşmiştir.

Çalışmanın temel amacı; Türkiye'de tarım politikalarında yaşanan değişmelerin işgücü piyasalarına olan etkilerini kadın işgücü ve tütüncülük faaliyetleri bağlamında analiz etmektir. Bu noktada geçmiş dönemlerde önemli bir tütüncülük merkezi olan ve tarım politikalarında yaşanan değişmelerden en çok etkilenen bölgelerden birisi olan Muğla ilinin Menteşe ilçesi çalışmanın örneklemini oluşturmaktadır. Bu kapsamda Menteşe ilçesinin önemli tütün üretim merkezleri olan Düğerek, Kötekli ve Yerkesik Mahallelerinden geçmişte tütüncülük faaliyetinde bulunan kadınlar ile iletişime geçilmiş ve derinlemesine mülakat görüşmeleri yapılmıştır. Çalışma kapsamında kadınlar ile yapılan derinlemesine mülakat görüşmeleri sonucunda; tarım sektörüne yönelik olarak yapılan yapısal düzenlemelerin ve özelleştirmelerin, tarımsal destekleme politikalarındaki radikal değişimlerin, tarımda çalışanları olumsuz olarak etkilediği görülmektedir.

Anahtar Kelimeler: İktisat, Makroiktisat, İşgücü Piyasası, Tütün Piyasası, Kadın İşgücü.

\section{Giriş}

Neolitik devirde başlayan tarımsal hayat insanoğlunun hayatta kalmasında başat rol oynamıştır. Bitki ve hayvan evcilleştirmesinin ortaya çıktığ1 Neolitik döneme, yani günümüzden kabaca 10,000 yıl öncesine kadar bütün insanlar avc1-toplayıcı idiler. Sanayi Devrimi'yle birlikte geleneksel tarım biçimleri, iki yüz yıla sığacak bir sürede hızla ortadan kalktı ve tıpkı dünyanın sınırlarına çekilen avcı-toplayıcılık gibi kendi dar alanlarına sıkıştı. Onun yerini makineli tarım, geleneksel üretim birimi olan köy ve onların beslediği küçük kentlerin yerini ise sanayinin yoğunlaştığı metropoller aldı. Buralarda büyük nüfus artışı yaşandı ve tarımla geçinen nüfusun oranı giderek azaldı. (Aydın \& Erdal, 2018: 119)

Küreselleşme ile birlikte yaşanan değişim ve dönüşüm piyasalarda da doğrudan yansımalarını bulmuştur. Uluslararası platformlarda uygulamaya konulan ekonomik politikalar, gerek ulusal gerekse bölgesel çerçevede yeniden düzenlenen politikalar aracılığıyla sektörel anlamda yapılandırma süreçlerini beraberinde getirmiştir. Tarım sektörü bu yapılandırma programlarından en 
çok etkilenen sektörler arasındadır. Gerek üretim gerekse tüketim bağlamında görünür olan bu değişimler tarım sektöründe zaten zorluklarla mücadele eden işgücünü yeni kısıtlarla karşı karşıya getirmiştir.

İşücü piyasası, emek arzı ve emek talebi olarak dikkate alındığında, küreselleşmenin ve beraberindeki teknolojik değişimlerin sonuçlarından önemli ölçüde etkilenmektedir. Küreselleşme süreci ile birlikte ortaya çıkan gelişmeler işgücü piyasalarının yapısını ve istihdam olanaklarını değiştirmektedir. (Çondur \& Bölükbaş, 2014: 77-93) Bu bağlamda küresel ölçekte tarım sektöründe yaşanan bu gelişmeler Türkiye'yi makro ve mikro boyutta etkilemiştir. Türk Tarım Sektörü içerisinde yer alan tütün ve tütüncülük faaliyetleri de özellikle istihdamın dağılımı noktasında bu etkilenmeden payını almıș, küresel politikaların Türkiye ölçeğindeki yansımaları Türk tarım sektöründeki istihdam yapısını değiştirmiştir. Bu çalışmada tüm bu gelişmeler ışığında Türk Tarım Sektöründeki istihdam yapısının değişimi, tütüncülük faaliyetlerinin ve kadın işgücünün söz konusu değişmelerden nasıl etkilendiği araştırılmıştır.

\section{1. İşgücü Piyasalarında Yapısal Dönüşüm, Türkiye’de Tarım Politikaları Ve Kadın} İşgücü

İşgücü piyasas1; işgücü arz ve talebinin karş1laştığ 1 , ücretin oluştuğu bir yer ve sosyal organizasyondur (Elliott, 1990: 4). Ekonomide mevcut birçok piyasa arasında ekonomik büyüme ve kalkınma amaçları gözetildiğinde etkinlik ve verimlilik açısından işgücü piyasası en önemli olanıdır.

1970'li yılların başında ekonomik bunalımları ve krizleri atlatma konusunda tıkanan kapitalist sistem değişim ve dönüşüm sürecine girmiştir (Harvey, 1993: 84). İlhan'a göre (2007: 283) kapitalist sistemin krizden çıkması için uygulanan esnek örgütlenme anlayışına dayanan yeni üretim sistemi, örgütlü kapitalizmin yeni koşullar temelinde inşa olmuş halidir. Post-fordist üretim sistemi olarak da bilinen bu yeni yapı için "birikimin neo-liberal aşaması" ifadesi de kullanılmaktadır. Değişim ve dönüşüm sonucu oluşan bu yeni ekonomik yapıda tüm dünya sermayenin mantığına teslim olmuş, üretimin yapısı ve süreçleri değişmiş ve gündeme gelen bu değişim kalıcı olmuştur. $\mathrm{Bu}$ süreç tüm piyasaları etkilediği gibi doğal olarak işgücü piyasasını da yakından etkileyerek değişime ve dönüşüme uğratmıştır.

Türkiye'de 1980 sonrası uygulanan yeniden yapılandırma politikalarıyla birlikte işgücü piyasası ise genel olarak düşük ücretli, niteliksiz, örgütsüz ve parçalı bir özelliğe sahiptir. Türkiye ekonomisinin bugün karşı karşıya olduğu en önemli ekonomik ve toplumsal sorun ise halen işsizliktir. TÜiKK verilerine göre, Türkiye genelinde işsizlik oran1 2018 y1lında \%1 1,4 olmuştur. Genç nüfusta (15-24 yaş) işsizlik oranı 1,6 puanlık artış ile \%21,6 olurken, 15-64 yaş grubunda bu oran 0,9 puanlık artış ile \%11,7 olarak gerçekleşmiştir. Genç işsizlik oranının erkeklerde \%18,6, kadınlarda ise $\% 27,2$ olduğu görülmektedir. Tarım dışı işsizlik oranı ise Türkiye genelinde 2018 y1lında \%13,5 seviyesindedir. Tarım dışı işsizlik oranının erkeklerde \%11, kadınlarda \%19,6 olduğu görülmektedir.

İstihdam edilenlerin sayısı 2018 yılı itibariyle, bir önceki yılın aynı dönemine göre 266 bin kişi artarak 29 milyon 63 bin kişi, istihdam oranı ise \%47,8 olarak gerçekleşmiştir. Bu dönemde, tarım sektöründe çalışan sayısı 264 bin kişi azalırken, tarım dışı sektörlerde çalışan sayısı 531 bin kişi artmıştır. Önceki yılın aynı dönemi ile karşılaştırıldığında tarım sektörünün istihdam edilenler içindeki payı 1,1 puan azalırken, sanayi sektörünün payı 0,8 puan, hizmet sektörünün payı ise 1,2 puan artış göstermiştir. Türkiye gibi gelişmekte olan ülkelerde büyük miktarda istihdam yaratmanın yolu etkin ve verimli ekonomik büyümeye bağlıdır. Türkiye ekonomisinde ekonomik büyüme; istihdam dostu büyümeye olarak da bilinen bir büyümeye dönüşmediği sürece işsizliğin azalması çok da mümkün olamayacaktır. İstihdam dostu bir büyüme için işgücü piyasalarının yapısal özelliklerinin ortaya konması, değişim ve dönüşümün istihdam arttırıcı olmasına imkân sunan politikaların geliştirilmesi gerekmektedir. 
Ekonomik büyüme ve kalkınma çabasında olan bir ülkenin, hızlı bir büyüme potansiyeli yakalayabilmesi için sanayi sektörüne dayalı bir kalkınma modelini seçmesi gerektiğini biliyoruz. Sanayileşme sayesinde belirli bir kalkınma hızı kazanıldığı zaman iki olay birlikte gerçekleşmiş olmaktadır (Eren, 2000:207). Bu durumun bir sonucu olarak da sanayi sektörünün istihdamdaki payının giderek artması beklenir.

Türkiye'de, TÜIKK verilerine göre, istihdamın sektörel dağılımına baktığımızda, 1988-2018 döneminde tarım kesimi istihdamı azalırken hizmetler ve sanayi kesiminin istihdam payları artmıştır. Gelişmiş ülkelerde \%3-5 civarında olan tarım istihdamına bakıldığında Türkiye'de tarım kesiminin $\% 19,5$ olan istihdam payı gelişmiş ülkelere kıyasla hala çok yüksektir. Tarım kesiminin payının bu kadar yüksek olmasının en önemli nedenlerinden biri sanayi sektörü yatırımlarının yetersiz kalması ve yeterli istihdamı yaratamıyor olmasıdır. Sanayi sektörünün istihdam içindeki payı ise artmıştır ve tarım sektörünün payı ile hemen hemen aynı oranda kalmışır. Ancak, \%19,6 olan sanayi sektörü payı, gelişmiş ülkelerdeki \%32-38 ile karşılaş̧ırıldığında istenen ekonomik gelişme rakamları açısından hala çok düşük kalmaktadır. Sanayi sektöründe artan istihdamın önemli bir bölümünün kayıtdışı ve düşük verimlilikte olması da göz önüne alınırsa bu artışın reel anlamda çok önemli bir artış olmadığı da ifade edilebilir (TÜİK, 2018).

2018 yılsonu itibariyle herhangi bir sosyal güvenlik kuruluşuna bağlı olmadan çalışanların yani kayıt dışı çalışanların oranı \%33,8 olarak gerçekleşmiştir. Tarım dışı sektörde kayıt dış1 çalışanların oranı ise bir önceki yılın aynı dönemine göre değişim göstermeyerek \%22'de kalmıştır. Türkiye'de son 20 yıllık dönemde hizmetler kesiminin istihdam içindeki payı ise hızlı bir artış göstermiştir. İstihdam içinde hizmet sektörünün payı $\% 54,3$ ile en yüksek paya sahiptir. Ancak, bu rakam gelişmiş ülkelerin hizmet sektörüne ait \%70'lerdeki istihdam payı düşünüldüğünde hala çok düşüktür. İnşaat sektörünün istihdam içerisindeki payı ise \%6,9 olarak gerçekleşmiştir (TÜİK, 2018).

Ekonomik gelişmenin sağlanabilmesi için, gelişmiş ülke örneklerine de baktığımızda, tarım sektöründeki gelişmelerin sanayileşmeye kaynak oluşturduğunu, sanayileşmenin gerçekleşmesi ile birlikte tarım sektörünün ekonomideki istihdam payı azalırken sanayi sektörünün istihdam payının arttığını daha sonra ise hizmet sektöründeki istihdamı arttırması gerektiğini bilmekteyiz. Gelişmiş ülkelerde sanayileşmenin önce sanayi sektöründeki istihdamı arttırdığını daha sonra ise hizmet sektöründeki istihdamı arttırdığını görmekteyiz. Ancak, Türkiye'de hizmet sektöründeki istihdam artışının, sektörler arası istihdam payları açısından "tarım-sanayi-hizmet" geçişini sağlamayarak, sanayi kesimindeki istihdam artışından daha hızlı gerçekleştiğini görmekteyiz. Başka bir ifade ile toplam istihdam içerisinde tarımın payı giderek azalırken, sanayi ve hizmet sektörünün payı artmakta ve özellikle sanayi sektöründe olması gereken istihdam artışı yaşanmadan hizmet sektöründe daha büyük artışlar görülmektedir. Bu durumun ise sektörlerin istihdam paylarının yıllar itibariyle beklenen resme uygun gelişmediğini, üretim ve verimliliği düşürerek ekonomik büyüme ve kalkınma açısından olumsuz etkiler ortaya çıkarttığını ifade edebiliriz.

Tarım ve tarım politikalarına bütüncül bir bakış açısı ile yaklaşmak oldukça önemlidir. $\mathrm{Bu}$ bağlamda birbirlerini tamamlayan ve destekleyen, hayvansal üretim ile bitkisel üretim birbirinden bağımsız düşünülmemelidir. Tarım sektörünün kalkınmada oynadığı öncü rol orta ve uzun vadeli tarım politikalarıyla ve reformlarıyla hayata geçirilebilir. Genel olarak Türkiye'de tarım sektörü kendine özgü bazı yapısal özellikleri ve beraberinde de bazı yapısal sorunları taşımaktadır.

Türkiye'de tarım sektöründe girdi (tohum, gübre, ilaç vb.) maliyetlerinin yüksekliği, dağınık yapıdaki üretici profili, tarımdaki plansız üretim, verimlilik ile ilgili yaşanan sorunlar, tarımsal verilerin ve veri tabanının sağlıklı olmayışı nedeniyle üretim planlamalarının tam ve doğru yapılamayışı, kamu kurum ve kuruluşlarının (Toprak Mahsulleri Ofisi, Tarım Kredi Kooperatifleri ve Tarım İşletmeleri Genel Müdürlüğü) ve kooperatiflerin işlevsellik sorunu ve AR-GE, inovasyon, ve katma değerli ürünlerin üretimi ve pazarlanması açısından üniversite, kamu ve özel sektör arasındaki yetersiz etkileşim gibi sorunlar bulunmaktadır. 
Bir tarım politikasından beklenenler (Çevik, 2017):

- Üretici gelirlerini arttırmak,

- Kırsal kesimin yaşam düzeyini iyileştirmek,

- Tarımda gelir dağılımını adil hale getirmek,

- Tüketicileri fiyat artışlarına karşı korumak,

- Rekabeti yüksek tarım ürünü yetiştirmek,

- Modern üretim tekniklerine uygun üretim yaparak ürün kaybını minimuma indirmek,

- Buzhane ve benzeri fiziki mekânları oluşturmak,

- Mevsimsel etkileri minimuma indirecek üretim tekniği geliştirmek,

- Etkin ve iyi tohum geliştirmek,

- Gübre üretimi yaparak dişa bağımlılığı azaltmak,

- Üretim maliyetlerini düşürmek,

- Üreticilerin üretimlerini doğrudan pazarlara ulaştırmasını sağlamaktır.

Türkiye'de tarihsel süreç boyunca tarımsal yapının en temel özelliği küçük aile işletmelerinin varlığ olmuştur. Geçmişten günümüze tarımdaki gelişmelerin iç dinamiklerini oluşturan yapılar içerisinde; mülkiyet ilişkileri, işletmelerin dağılımı, kırsal alanda küçük işletmelerin geçimlik düzeyde tarımla uğraşması, büyük toprak sahiplerinin (neredeyse toprakların \%70'ine sahiplerdi) tarımla uğraşanların gelirlerine ortak oluşu gibi nedenler sıralanabilir (Gönel, 2013:332).

1950'li yıllara kadar olan dönemde ülkenin toplam ihracatının büyük bir kısmı ticari tarım ürünlerinden karşılanmaktaydı. O dönemlerdeki başlıca tarım ihraç ürünleri; tütün, findık, pamuk, üzüm ve incirdi. Örneğin 1923-1928 yılları arasında tütün, toplam ihracatın ortalama \%30'unu sağlıyordu. Dünyada tarımsal ürün fiyatlarının oldukça yüksek seyrettiği bu yıllarda, tarımın Türkiye'nin kalkınmasında ilk ciddi katkısı ihracat yoluyla olmuştur. Ancak daha sonra dünyada tarımsal üretim fazlasının yaşanmasıyla bu fiyatlar düşmeye başlamıştır (Gönel, 2013:332). 1950'li yılların tarımsal dönüşümünde ise dışsal faktörler ve Marshall yardımları öne çıkmaktadır. Ülkede tarımın kalkınmaya katkısının en çok konuşulduğu dönem yine 1950’li yıllar olmuştur. Esas olarak da 1946-1953 yılları tarımsal gelişme yılları olmuştur. Dönem boyunca tarımın ortalama büyüme hızı \%13,2'yi bulmuştur (Boratav, 2003:101).

Planlı karma ekonomi dönemi olan 1961-1979 döneminde şunlar dikkati çekmektedir. Tarımda makineleşme ve bu konuda teşvik politikası uygulaması, kredi olanaklarının arttırılması, yerli sanayinin korunması, önceleri dış yardımların tarımda kalkınma amacıyla kullanılması, sonraları sanayi kesiminin ekonomik büyüme açısından lokomotif kesim olarak tanımlanması, ithal ikameci ve ihracatın teşviki gibi politikaların benimsenmesi söz konusu olmuştur (Eğilmez \& Kumcu, 2018:255-256).

Ekonomilerde dönüşümlerin hızlandığ 1980'li yıllar ve o dönemde artan liberalizasyon ile birlikte ekonomiler dışa açılmış ve rekabet etmenin önem kazandığı bir dönem başlamıştır. Yeni dönemle birlikte Dünyada ve Türkiye'de yeni tarım politikaları belirlenmiş, özellikle Türkiye'nin Avrupa Birliğiyle başlatmış olduğu gümrük birliği ve dış ticarette gümrük vergilerinin tarım ürünleri ve bazı ürünlerde sıfırlanmasıyla rekabet gücü daha ön plana çıkmıştır. Gümrük birliğinin getirmiş olduğu koşullarla birlikte daha etkin tarım politikaları belirlenmesinin gereği artmıştır (Çevik, 2017). 1980 sonrası süreçte ise, liberal politikaların izlenmesiyle, tarımsal destekler önemli ölçüde azalmıştır.

1990’lı yıllarda Türkiye tarımı açısından önemli kurumlar özelleştirilmiştir. 1994 krizi dönemi de tarım sektörünün en çok kaybettiği dönemler arasında yer almıştır. Kamu harcamalarını azaltıcı (kaydırıcı) politikalar çerçevesinde 1994 krizi sonrası desteklemeye konu olan tarımsal ürün 
sayıs1 26'dan 9'a düşürülmüştür (Günaydın, 2010: 164). Hatta ülke tarımında en dramatik yapısal dönüşüm 17. Stand-by anlaşmasıyla 1999-2008 döneminde gerçekleştirilmiş ve bu anlaşma ile IMF ve Dünya Bankası'na verilen sözler; fiyat, fiziki sınırlama, mali destek sınırlamaları ve özelleştirmeler olarak dikkat çekmiştir.

Tarım üretimindeki girdi fiyatları, tarımsal ürün fiyatlarından daha hızlı arttığı için, tarım kesimi sürekli işletme kredisi bulmak ve aracıya borçlanmak durumu ile karşı karşıya kalmıştır. Özellikle taban fiyatı uygulamalarının kamu harcamalarının artmasında etkili olduğu ve Türkiye'nin Kamu Kesimi Borçlanma Gereksinimini arttırdığ 1 düşüncesiyle özellikle 1980'lerden sonra bu uygulama azaltılmaya çalışılmış, yaşanan 2000-2001 krizinin ardından destekleme alımları pek çok üründe kaldırılarak, yerine doğrudan gelir desteği programı konulmuştur. Ayrıca tarım kesiminden alınan vergi ile tarım dışından alınan, (örneğin sermaye gelirlerinden alınan) vergi arasındaki fark, tarım kesiminin aleyhine devam etmektedir (Gönel, 2013:333).

Tarım sektöründe yaşanan yapısal değişim ve dönüşümün arka planında yer alan tarım politikaları, bu sektörde istihdam edilen bireylerin hayatlarını da doğrudan farklı bir alana taşımıştır. Tarım sektöründe yaşanan mülkiyet değişikliği, tarım ilgili alınan politik kararlar ve bu kararlardan doğrudan etkilenen tarımsal işgücünün evrilmesine yol açmış, tarım sektöründe yoğun olarak istihdam edilen kadın işgücü de bu değişimden olumsuz etkilenmiştir.

Gerek dünya genelinde gerekse ulusal düzeyde nüfusun yaklaşık yarısını kadınlar oluşturmaktadır. TÜİK verilerine göre 2018 yılı sonu itibariyle Türkiye nüfusunun \%49,8'ini kadınlar, \%50,2'sini ise erkekler oluşturmaktadır. Nüfusun yaklaşık yarısını teşkil eden bu orana rağmen işgücü piyasasında kadınlar aynı oranla temsil edilmemektedirler. (Karataş, 2015: 22). Türkiye'de de kadın işgücüne yönelik gerçekler dünya genelinden çok farklı değildir. Türkiye'de kadınların işgücüne katılım oranları erkeklere kıyasla son derece düşük bir seviyededir. TÜíK verilerine göre, 2018 yılı sonu itibariyle erkeklerin \% 73,5'i işgücüne katılırken, kadınların ise sadece $\% 34,9$ ’u işgücüne katılıyor. Kadın ve erkek arasındaki işgücüne katılma oranındaki farklılığın en temel sebebi toplumsal cinsiyet eşitliğinin istenen düzeyde sağlanamaması ve hala işgücü piyasalarında cinsiyete dayalı işbölümünün var olmasıdır.

Türkiye'de kadınların işgücüne katılım oranının düşük olması kentleşme olgusuyla da yakından ilgilidir. Kırsaldan kente göç bu anlamda işgücüne katılma oranlarını etkilemiştir. Kırsaldan kente göçün en önemli nedenlerinden biriside tarım sektöründeki yapısal dönüşümdür. Kırsal kesimde kadın, tarım sektöründe ücretsiz aile işçisi olarak ekonomik faaliyete katılmakta iken kente göç ile kadının işgücüne katılım oranı düşmektedir. Kırsal kesimde yaşayan kadınlar ekonomik getirileri ve sosyal güvenlikleri olmaksızın ücretsiz aile işçileri olarak işgücüne katılmakta, kentlerde yaşayan kadınların önemli bir kısmı ise, ev kadını adı altında işgücüne dâhil edilmemektedir. İ̧̧ü̈cü hesaplamalarına dahi katılmayan bu kadınların işsiz kalmaları da teorik olarak mümkün olamamakta, dolayısıyla bu kadınların işsizliğinin önlenmesi hususu herhangi bir istihdam politikasında yer almamaktadırlar (Önder, 2013: 36). Bu durum Türkiye'de kadın istihdamı sorununun aslında görünenden daha derin ve büyük olduğunun bir göstergesidir. Tarımdaki yoksullaşmanın sonucu olarak kırdan kente göç etmek zorunda kalan nüfus içinde kadınlar ya işsiz kalmış ya da ucuz ve güvencesiz işlerde çalıştırılmışlardır.

Türkiye'de de kadın işgücü ikincil işgücü statüsünde, ucuz işgücü tanımında düşük ücretli, düşük statülü işlerde ve genellikle hizmet sektöründe toplumsal cinsiyete dayalı kadın rollerinin devamı olan işlerde istihdam edilmektedir. İstihdam edilenlerin işteki durumlarına cinsiyet bazında ayrıştırılarak bakıldığında kadınların \%25,3'si ücretsiz aile işçisi (erkeklerde \%4,6); \%64,3'ü ücretli ve yevmiyeli (erkeklerde \%69,5) ve \%10,3'ü kendi hesabına ve işveren (erkeklerde \%25,9) konumunda oldukları görülmektedir (TÜIK, 2018).

Kadın işgücü istihdamındaki artış, tarım sektöründen sanayi ve hizmetler sektörüne işgücü akımını da beraberinde getirmiştir. Başka bir ifade ile işgücü piyasasındaki yapısal değişim ve 
dönüşüm sonucu kadın işgücünde sektörlerin ağırlıkları açısından da bir değişim yaşanmıştır. Özellikle hizmet sektörü göreceli olarak, tarım ve sanayi sektörünü geride birakarak istihdam yaratma açısından hızlı bir şekilde büyüme göstermektedir. Hizmet sektörünün ağırlık kazanmasına paralel kadın işgücünün istihdamdaki ağırlığının arttığı da görülmektedir. TÜİK 2018 verilerine göre, Türkiye'de işgücüne dâhil olan kadınların \%28,3'ü tarım sektöründe, \%14,4'ü sanayi sektöründe, $\% 0,8$ 'i inşaat sektöründe ve \%56,5'i hizmetler sektöründe istihdam edilmektedir. Kadın işgücünün sektörel dağılımında belli sektörlerin ve iş kollarının ön plana çıtı $\breve{1}$ görülmektedir. Bu sektörler içinde tarım sektörü önemli bir paya sahiptir. İmalat sanayi ve hizmet sektörü de yine kadın işgücünün yoğunlaştığı sektörler arasındadır.

Tarım sektöründe yaşanan bu dönüşüm bir tarım alt sektörü olan tütüncülük faaliyetlerinde de kendisini göstermiş, 4733 sayılı Tütün Yasasının yürürlüğe girmesiyle; destekleme alımlarına son verilmesi, sözleşmeli üretim modeline geçilmesi ve ilerleyen süreçte TEKEL'in özelleştirilmesi ile birlikte üretim miktarında ve üretici sayısında önemli azalmalar meydana gelmiştir.

TÜIK' 'in 2018 yılına ait verilerine bakıldığında 56 bin sözleşmeli üretim yapan üretici olduğu ve 943 bin dekar alanda 82,5 milyon kilogram tütün üretimi yapıldı̆̆ı görülmektedir. Son 16 yıllık süreç içerisinde tütüncülük faaliyetleri incelendiğinde; 2002 yılında 405 bin kişi olan tütün üreticisi sayısının 2018 yılında 56 bin kişiye düştüğü, 2002 yılında159.521 ton olan üretim miktarının ise 2018 yılında 82.500 tona gerilediği gözlenmektedir. Söz konusu bu 82.500 ton toplam Sözleşmeli tütün üretimi miktarının, \%75' i Ege Bölgesinde gerçekleşmektedir.

\section{Muğla İlinde Tütüncülük Faaliyetleri Ve Kadın İşgücü}

Muğla ile potansiyeli itibari ile başta tarım, madencilik ve turizm sektörü olmak üzere birçok rekabetçi avantajları nedeniyle Türkiye ekonomisi için çok önemli bir il konumundadır. Özellikle dağlık ta olsa büyük bir coğrafi ve tarımsal alana, ormanlara ve özelliklede oldukça uzun bir kıyı şeridine sahip olan Muğla ili her ne kadar potansiyelinin altında bir görünüm seyretse de başta turizm sektörü olmak üzere önemli bir destinasyon merkezidir ve nüfus yapısı itibariyle de çok önemli bir tarımsal üretim merkezidir.

Dağlık bir arazi yapısına sahip olan Muğla tarımsal üretime uygun gibi görünmese de Türkiye'nin önemli bir tarım merkezidir ve bu makalenin ana konusunu oluşturan tütün üretimi noktasında Türkiye'de y1llar itibari ile ilk dört içerisinde yer alan çok önemli bir tütün üretim merkezidir.

Her ne kadar 2002 yılı ile başlayan kota uygulaması ile tütün piyasalarının tamamen serbest piyasa koşullarına bırakılması, tütün üretiminde sözleşmeli üretim modeline geçilmesi, TEKEL'in özelleştirilmesi ile yabancı firmaların piyasaya hâkim olması gibi temel nedenlerle tütün üretiminin Muğla ili genelinde azalması kaçınılmaz olmuş olsa da tütün hala Muğla için çok önemli bir tarımsal üründür. TÜİK (2018)'e göre Muğla ilinde 1991 yılı itibari ile 12.360 ton olan tütün üretimi Tütün üretimi için kritik bir yıl olan 2002 yılında neredeyse yarı yarıya azalmış ve 6.326 tona ulaşmıştır. 2017 yılı itibari ile bakıldığında ise Muğla ilinde tütün üretimi neredeyse 5 kat azalmış ve 1.561 tona gerilemiştir.

Muğla'da yapılan tütün ekiminin ise daha ziyade eski ismi ile Merkez ilçe 2013 yılı itibari ile Menteşe ilçesinde yoğunlaşmış olduğu ve tütün üretiminin neredeyse tamamına yakınının (2017 y1lı itibari ile 1268 ton) Menteşe ilçesinde gerçekleştiği görülmektedir. Bu bağlamda bu çalışma için derinlemesine mülakat yapılan bölgenin Muğla Menteşe ilçesine bağlı önemli tütün üretim merkezlerini içerisine alan Düğerek, Kötekli ve Yerkesik mahalleleri olarak seçilmesinin temel gerekçesini de söz konusu bu tablo oluşturmaktadır (TÜİK, 2018).

Diğer taraftan son 15 yıllık süreçte TÜİK (2018) verilerine göre Muğla ilinde önemli bazı gerekçelerle tütün üretimi yaklaşık 84 bin tondan, 16 bin tona düşmüştür ve tütün üretiminde ciddi bir azalma yaşanmıştır. Söz konusu bu gerekçeler neler olabilir sorusunun cevaplanması noktasında 
bir sonraki bölümde derinlemesine mülakat yöntemi kullanılarak tütün üretimi içerisinde bulunmuş kadınlar ile irtibata geçilmiştir. Çalışmada kadın işgücü üzerinde durulmasının temel nedeni özellikle kadınların tarımsal üretim faaliyetlerinde ve özelliklede tütüncülük faaliyetlerinin her aşamasında yoğun olarak çalışması ve yukarıda da değinilen nedenlerle tarım politikaları ile işgücü piyasalarında yaşanan değişmelerin olumsuz etkilerinin kadınlar üzerinde çok daha belirgin olmasıdır.

\section{Araştırma Yöntemi}

Çalışmadaki temel amaç nesne ve ilişkilere ait nedensel güçleri ortaya çıkartmak, sadece öne çıkan sonuçları ya da baskın olan bulguları incelemek değil örtülü kalmış unsurları da belirlemektir. Bunun için araştırma yöntemi olarak derinlemesine mülakat tekniği tercih edilmiştir. Araştırma konusunun tarafları ya da etkileşim gruplarına dâhil olan bireylerin özgürce fikirlerini, sorunlarını ve çözüm önerilerini paylaşma konusunda etkinliği yüksek olan derinlemesine mülakat tekniğinin en belirgin avantajlarından biri farklı ve yeni bulgulara ulaşmayı kolay kılmasıdır. Kitzinger (1995)'in de ifade ettiği gibi sosyal bilimlerde sıklıkla kullanılan bu teknik en sistematik veri toplama yöntemlerinden biridir. Özellikle sosyal bilimlerde görünenin altındaki gerçekleri ortaya çıkartmak için ve sosyal gerçekliklerin açıklanmasında nitel teknikler temel alınarak nicel teknikleri destekleyici olarak kullanılması daha verimli sonuçlar elde etmeye olanak sağlamaktadır.

Araştırmada ana kütle Muğla ilinde tütün sektöründe faaliyet göstermiş kadın işgücüdür. Araştırmanın çalışma grubu ise Muğla ilinde tütün sektöründe öne çıkan beldelerde aktif tütün faaliyetinde bulunmuş kadınlardır. Çalışma grubunu oluşturan 9 kadına, tarım politikaları bağlamında işgücü piyasalarında ortaya çıan yapısal dönüşümün kadın işgücü açısından sonuçlarını tespit etmeye yönelik derinlemesine mülakat tekniklerine uygun hazırlanmış toplamda 32 soru yöneltilmiştir. Sorulardan 9'u demografik, 23'ü ise açık uçlu soru niteliğindedir.

\section{Araştırma Bulguları ve Tartışma}

Çalışmada Muğla ilinin farklı beldelerinde tütün sektöründe faaliyet göstermiş 9 kadın ile yapılan derinlemesine mülakat görüşmeleri sonucunda katılımcılardan elde edilen bulgular aşağıda sunulmuştur. Çalışmadaki katılımcılar (K):

(K.1) 63 yaşında, evli ve 1 çocuk annesi, ilkokul 4'ten terk,

(K.2) 51 yaşında, bekar ve 2 çocuk annesi, ortaokul mezunu,

(K.3) 48 yaşında, evli ve 2 çocuk annesi, ortaokul mezunu,

(K.4) 36 yaşında, evli ve 1 çocuk annesi, ilkokul mezunu,

(K.5) 48 yaşında, evli ve 1 çocuk annesi, ilkokul mezunu,

(K.6) 66 yaşında, evli ve 2 çocuk annesi, ilkokul mezunu,

(K.7) 68 yaşında, evli ve 3 çocuk annesi, ilkokul mezunu,

(K.8) 44 yaşında, bekar ve 1 çocuk annesi, lisans mezunu,

(K.9) 59 yaşında, evli ve 2 çocuk annesi, ilkokul mezunudur. ulaşılmıştır:

Yapılan derinlemesine mülakat görüşmeleri demografik açıdan incelendiğinde ise şu verilere

Araştırma, işgücü piyasalarında yapısal dönüşüm bağlamında kadın işgücünün durumunu analiz ettiği için örneklemin tamamını kadınlar oluşturmaktadır. Görüşme yapılan kadınların yaş aralıkları; \% 11,1 ile 36-42 yaş aralığında, \%33,4 ile 43-49 yaş aralığında, \%11,1 ile 50-56 yaş aralığında, \%22,2 ile 57-63 yaş aralığında ve yine \%22,2 ile 64-70 yaş arasındadır. Katılımcıların eğitim durumları incelendiğinde; \%55,6'sının ilkokul, \%22,2'sinin ortaokul, \%11,1'inin lisans ve $\% 11,1$ 'inin ise ilkokul 4. Sınıftan terk yani ilkokul mezunu bile olmadığı tespit edilmiştir. Görüşme 
yapılan kadınların medeni durumları incelendiğinde ise \%77,8'inin evli, \%22,2'sinin ise eşinden ayrıldıkları ve bekâr oldukları sonucuna ulaşılmıştır.

Elde edilen bulgular doğrultusunda görüşmeye katılan kadınların \%44,5'inin hanehalk1 sayısının 3, \%33,3'ünün hanehalkı sayısının 2, \%22,2'sinin hanehalkı sayısının 4 kişi olduğu tespit edilmiştir. Kadınların Hanehalkı gelirleri incelendiğinde \%55,6'sının 1.000-2.500 TL gelir aralığında, \%11,1'inin 2.600-4.000 TL gelir aralı̆̆ında ve \%33,3'ünün ise 4.100-5.500 TL gelir aralığında oldukları görülmüştür. Görüşme yapılan kadınların \%55,6'sı bireysel gelire sahip değilken \%44,4'ü bireysel gelire sahiptir. Bireysel gelir elde eden kadınların \%25'i devlet memuru olarak 4.200 TL gelir elde etmektedir ve hanehalkını geçindirmekle yükümlüdür. Bireysel gelir elde eden diğer kadınların \%50'si asgari ücret düzeyinde gelir elde ederken; \%11,1'i ise kayıt dışı çalışmakta ve $1.500 \mathrm{TL}$ yani asgari ücretin altında gelir elde etmektedir.

Alan çalışması dâhilinde derinlemesine mülakat görüşmesi yapılan kadınlara, hiç çalışma hayatında bulundunuz mu? Bulundunuz ise hangi işlerde çalıştınız? sorusuna alınan cevaplarda çok küçük yaşlardan itibaren hepsinin daha önce çalışma hayatında bulunduğunu ve çoğunun tarım ve hayvanc1lık gibi sektörlerdeki işlerde istihdam edildikleri görülmektedir.

“Çocukluğumda koyun kuzu güddüm. Ailem hayvancılıkla ilgileniyordu çobanlık yaptım. Evlendikten sonra da kendim tütün işçisi olarak çalış̧ım." (K.1)

“Çocukluğumdan beri tütünde çalıştım sadece. 10 yaşımdan 25 yaşıma kadar tütünde çalıştım." (K.4)

"11 yaşında okuldan çıktım tütünde çalışmaya başladım. Ailem tütün yapıyordu bende onlarla çalışmaya başladım. 2010 yılında 1 yıl otelde çalıştım. 2011 yılında okulda hizmetli olarak işe başladım halen de okulda çalışıyorum." (K.3)

Katılımcılara tütün sektöründe çalışmaya nasıl başladıklarına ve ne kadar süre bu sektörde çalıştıklarına yönelik sorulara alınan yanıtlarda ise katılımcıların genellikle ücretsiz aile işçisi statüsü ile bu sektörde çalışmaya başladıkları görülmektedir. Ayrıca görüşme yapılan kadınların yanıtlarında uzun yıllar Muğla ilinde tütüncülük faaliyetlerinde çalıştıkları tespit edilmektedir.

"Anne babamdan göre göre başladım, ailemle başladım... Anne babamın arkasında çocukken yetiştik işte... Doğduğumdan beri yaptım yaklaşık 40 yıl yaptım...” (K.9)

“Küçüklüğ̈̈mden beri ailemle tütünde çalışarak başladım. 10 yaşımda başladım tütü̈nde çalışmaya. Halen tarım işi yaptyorum. Son 10 yıldır burada artık tütün işi yapan yok.”(K.7)

"40 yıl tütünde çalıştım. 9-10 yaşlarında başladım çalışmaya. Küçükken uykudan uyandırır tütü̈ne götür rürlerdi. Her yaş çocuğun yapacağı tütün işi ayrı olurdu tarlada. Makine çıktı tütün kolaylaştı biz tütünü bıraktık.”(K.6)

Tütün sektörünün artık cazibesini kaybetmesi nedeniyle bu alanda faaliyet göstermeyi bırakmış olan kadınların şu an çalışıp çalışmadıklarına yönelik sorulan sorulara alınan yanıtlarda çoğunluğunun çalışmaya devam ettiği, çalışmaya devam eden kadınların ise genellikle tarım ve hizmetler sektöründe istihdam edildikleri görülmektedir.

"Şu an bahçeyle uğraşıyorum. Sebze ekip biçiyorum. Satıyorum sebzemi. Başka işle hiç uğraşmadım hep toprakla uğraştım.” (K.7)

“Evet, şu anda bir okul kantininde çalışlyorum.” (K.5)

"Şimdi băg bahçe hayvancılık tarım sektöründeyiz yine, iki tane ineğimiz var işte, dünya geçimi..." (K.9)

"Çalışıyorum. Çalışmaya mecburum. Evde çocuk bakıyorum. Arada sırada da evlere temizliğe gidiyorum” (K.2) 
“Şu anda devlet hastanesinde hemşire olarak çalışıyorum devlet memuruyum yani.” (K.8)

"Bakkal dükkant işletiyoruz. Halen aileye destek olmak adına neredeyse her gün bakkalda aileme destek oluyorum. Som zamanlarda eşimin kolunda kırık olması nedeniyle dükkana daha çok gelir oldum."(K.4)

Görüşmeye katılan kadınlardan ikisi ise artık çalışmadıklarını belirtmişlerdir. Bunlardan birisi yaşının ve sağlığının artık çalışmaya uygun olmadığını, diğeri ise çalışabileceği bir iş olmadığını ifade etmiştir.

Daha önce tütün sektöründe istihdam edilmiş kadınların, şu an tütüncülük faaliyetinin büyük oranda ortadan kalkması nedeniyle, ücretsiz aile işçisi olarak tarım ya da hayvancılık yaptıkları, hizmetler sektörüne geçiş yaptıkları, bazılarının bakım ve temizlik işlerinde kayıı dışı çalıştıkları ya da çalışma hayatının dışında kaldıkları görülmektedir. Bu anlamda görüşme yapılan kadınlara ne zaman ve hangi sebeplerle tütünde çalışmayı bıraktıkları ve ayrıca bu durumun hayatlarında neleri etkilediği yönünde sorulan sorulara alınan yanıtlar ise aşağıda sunulmuştur.

"10 seneyi geçti tütünü bırakalı, Yaş itibariyle bıraktım, para da etmemeye başladı bir de çok zordu tütünde çalışmak. Tütünü bırakınca vakit de geçiremeyiz diyorduk ama hiç aklımıza bile gelmedi. Bıkmışız.” (K.6)

"Evlenip şehre göçünce tütünde çalışmayı bıraktım. Tütünde çalışmayı bırakmak gelirimizi azalttı. 3 ay çalışıordum ama toplu para alıyordum. Güzel kazantyorduk.”(K.3)

“10 yıl kadar önce bıraktık... Tütünü TEKEL almayacağım dedi birde kota koydular 5055 diye, sonrada parasını birer lira tuttular mi, bir balyan varsa 55 liradan biz hiç para kazanamadık ondan sonrada baktık bütü̈n zarardayı bıraktı...”(K.9)

Alan çalışmasına katılan ve daha önce tütüncülük faaliyeti gösteren kadınların refah seviyelerinde değişim olup olmadığı, oldu ise hangi yönde olduğunu tespit etmeye yönelik tütünde elde ettikleri gelir ile şu anki gelirlerini kıyaslamaları ve yaşam standartlarını karşılaştırmaları istenmiştir. Elde edilen bulgular doğrultusunda katılımcıların bazılarının tütün yaptıkları dönemde gelir seviyelerinin ve refah seviyelerinin daha iyi olduğu, yaşam standartlarının daha yüksek olduğunu ifade ettikleri görülmektedir.

"Ailem tütün yaparken maddi durumumuz gayet iyiydi. Babamlar beni tütünden kazandırdıklarıyla evlendirdi. Düğ̈̈nümü o kazançla yaptı. Çeyizimi o parayla aldık. Sonra evlendikten sonra tütüne giderdim eski kocamda işçiydi onun kazancı ile evi geçindirirdik benim kazancımla ev yaptık. Şu anda çocuk baktyorum elde ettiğim kazanç tütünden çok az. Nasıl diyeyim tütünde bunun 3 katını kazanırdım. Refah seviyem baya düştü. Tütün özellikle biz kadınlar için okumayan bir işi olmayan kadınlar için ekmek kapısıdd hem de parası karlı bir ekmek kapısiydı."(K.2)

"2000’den önce tütünden kazanmak iyiydi ondan sonra kötülești. 30 balya tütün yapardık, sonraları 15 balya yapın dediler. 15 balya tütün yaptık o da para etmeyince azar azar birakttk gitti...."(K.6)

"Yıllık toplamda şu ankinden daha fazla para kazanırdık. Refah seviyemiz yüksekti ama sonraları tütün para etmez oldu. Şu anda asgari ücretle çalışıyorum.”(K.3)

“... TEKEL kapatılmasa tütüncülük devam ederdi diye düşünüyorum... bizim için sıkıntı yoktu ailelerimizde para olurdu ne zaman istesek para sorunu olmazdo refah düzeyimiz de iyiydi. Şu anda ise başka gelir kaynaklart yok...” (K.8)

"Tütünü bırakmak her şeyimizi etkiledi tütün bizim ekmeğimiz aşımız idi... Çok etkiledi ondan sonra mallan uğraştık, domates ektik karpuz ektik... İşste ayağımızın üzerinde durduk, ne ileri gittik ne geri geldik ayă̆ımızın üzerinde kaldık... Tütünü bırakmak iyi olmadı...”(K.9) 
Alan çalışmasına katılan bazı kadınlar ise tütünden elde ettikleri gelirin sezonluk olduğunu, çok fazla olmadığını, özellikle son dönemlerde gelirlerinin hayatlarını asgari düzeyde idame ettirecek düzeyde kaldığını, çalışma şartları ile değerlendirildiğinde rezillik ve perişanlık yaşadıklarını ifade etmektedirler. Ancak yine de refah ve yaşam standartları açısından şu an daha iyi olduklarını maalesef ifade etmedikleri de dikkat çekmektedir.

"Tütünden başlarda iyi gelir elde ediyorduk sonra ise boğaz tokluğuna, günlük ihtiyaçlarımızı karşılayacak kadar, yiyecek paramızı kazanacak kadar gelir elde ettim. Ben sonraları kendi bahçemde tütün yaptım. Bahçemizde küçüktü o nedenle çok büyük paralar kazanmadım. Kendimize yetecek kadar para kazandım.”(K.1)

Çalışmada elde edilen bulgularda eskiden tütünde işçi olarak çalışan ya da kendi hesabına tütün yapan kadınların büyük bir kısmının şu anda farklı sektör ve pozisyonlarda çalışmaya devam ettikleri tespit edilmiştir. Sosyal güvence durumu ile kayıt dışı çalışma durumunun olup olmadığını tespit etmeye yönelik olarak sorulan sorulara alınan cevaplarda tütün faaliyeti yaptıkları dönemde hiçbirinin sosyal güvencesi olmadığ 1 tespit edilmiştir. Şu an çalışanların bir kısmı sosyal güvenceye sahip iken bir kısmının ise kayıt dışı çalıştıkları gözlenmektedir.

"Tütünde çalışırken sosyal güvencem yoktu. Bekarken babamın üzerinden evliyken kocamın üzerinden vardı. Şimdi ise evde çocuk baklyorum, bir sosyal güvencem yok.” (K.2)

“O dönemde sigorta yoktu, şimdi eşimde BA $\breve{G}$-KUR var ama o da yatmıyor zaten düşük gelir yüzünden.”(K.4)

“Tütünde çalışırken sosyal güvencem yoktu ama şimdi sigortalı çalışıyorum.”(K.3)

“Tütünde çalışırken de şimdi de sigortam yok.”(K.6)

“Tütünde çalışırken sosyal güvencem yoktu ... Şimdi tarım bağ kuru yatırıyorum...”(K.9)

Alan çalışmasında katılımcı kadınlara tütün sektöründe çalışmaktan mutlu olup olmadıkları sorulmuştur. Alınan yanıtlarda kadınların bazılarının tütün işçiliğinin çok zahmetli ve zor olduğunu bu nedenle mutlu olmadıklarını belirttikleri görülmektedir.

"Tütünde çalışırken mutlu değildim. Sevmiyordum zorla işliyordum. Mecburiyetten. Gece erkenden kalkyorduk sabah ezanında kalkyorduk tarlaya gidiyor fidan yoluyorduk. Çok zor çalışma koşulları vardı. Şimdiki gibi kolay değildi hiçbir şey. Her aşaması tütün iş̧̧iliğinin çok zordur. Ekimi dikimi toplaması her aşaması zor ve yorucudur. Gün doğdu mu saat sabah 9-10 oldu mu zaten tütün buruşur toplanmaz o nedenle tütün işi gece işidir, tütü̈nü gece kırarız. Gündüz de ev bağ bahçe hayvanlar çoluk çocuk işi yapılır. Eeee uyumaya bile vakit kalmazdı tütünde çalışırken.” (K.1)

"Tütünde çalışmak mutluluk vermiyordu. Yorgunluk, uykusuzluk, kir, pas, gece mesaisi mutsuzdum. Böyle daha iyi daha düzenli, üstüm başım temiz en azından.”(K.5)

Alan çalışmasına katılan kadınların bir kısmı tütünde çalışmanın iyi para kazandıkları dönemde kısmen mutluluk verdiğini ancak tütünden zahmetlerinin karşılığ 1 olan geliri elde edemedikleri dönemlerde ise bu işi yapmaktan memnun olmadıklarını ifade etmektedirler.

“İyi para kazanmak güzeldi. Ama tütün çok zor bir iştir. Çok yoruluyorduk. Ama yoksulluk çekmiyorduk. Şimdi elin çocuklarına bakıp ekmek parası kazanıyorum.”(K.2)

Çalışmadaki katılımcıların bir kısmının ise tüm çalışma zorluklarına rağmen sosyal ilişkiler, hep birlikte çalışmanın verdiği haz, üretmenin şevki ve çalışmayı eğlenceli hale getirdikleri etkinlikler ve benzeri birçok sebeple tütün işçiliği yaptıkları dönemde mutlu olduklarını ifade ettikleri görülmektedir. 
"Çok mutluydum. Komşuluk ilişkilerimiz çok iyiydi. Türkü söyleye söyleye tütün kırardık, gelirdik çayımızı içerdik. Şimdi karardık, içimiz karardı. Komşu iliş̧kileri o zamanlar daha güzeldi. Birbirlerinin evinde sohbetler vardl. Tütün dikmeye gelen ameleler de türkü söylerdi. (Bunlar tarlayı kiralayan patronumsulardı sanırsam)erkekler arık çekerdi, kadınlar arkalarında tütünü ekerdi. Ama geceleri sabaha karşı üçte dörtte kalkardık. Eskiden kart-koca-çoluk-çocuk hep birlikte çalışılırdı.” (K.6)

“Tütündeyken çok mutluyduk, vücudumuzun pis terini atıyorduk.”(K.7)

"Tütün yaparken çocuktuk ve etrafimızdaki herkes tütünle uğraştığı için zengin fakir ayrımı olmadığı için biz çok mutluyduk. Sabah bile erkenden hayıflanmadan kalkardık çünkü komşumuzun oğlu da kızı da hep aynı saatte kalkardı kıyaslama şansımız yoktu. Birde imece usulü çok olduğu için onlar bize gelirdi biz onlara giderdik mutlu bir şekilde yapardık tütünü. Alışkanlıktı birde onun için mutluyduk." (K.8)

Çalışmada daha önce tütünde çalışan kadınlara tütünde çalışmayı bıraktıktan sonra iş arayıp aramadıkları, çalışmak isteyip istemedikleri ve eğer çalışma hayatına devam ettilerse iş arama süreçlerinin nasıl işlediği sorulmuştur. Katılımcıların bazıları iş aramadıklarını, ailelerinin tarım ile ilgilendiğini onların da ücretsiz aile işçisi olarak tarım ve hayvancılıkla uğraşmaya devam ettikleri görülmektedir.

"Yok, aramadım iş. Evin bahçesinde bir şeyler ektik. Bir tane ineğimiz vardı sütümüzü̈ yoğurdumuzu yaptyorduk ama belediye geldi 250 TL ceza kesti bize ineği sattırd."(K.6)

"Tütünden sonra iş arama gibi bir durumum olmadı tarıma devam ettim... Daha hala devam ediyoruz...”(K.9)

Bazı katılımcılar ise evlendiği için iş aramadığını ya da çalışabilecek işler olmadığı için iş aramaya gerek duymadığını belirmektedirler.

“Hayır, aramadim zaten evlendim." (K.4)

"Tütünden sonra iş aramadım. İşler hep dışardaydı ben de dışarı gidemiyordum. Buralarda iş olsa çalışırdım ama iş yoktu. Sigortalı bir iş olsa çalışırdım.” (K.1)

Bir katılımcı ise (K.8) lisans mezunu olduğunu hemşirelik okuduğunu ve tütünü bıraktığ1 dönemde ataması geldiği için devlet memuru olarak çalışmaya başladığını ifade etmiştir.

Alan çalışmasına katılan kadınların bir kısmı ise çalışmaya devam etmek istedikleri ya da çalışmaya mecbur oldukları için iş aradıklarını belirtmişlerdir. Bu kadınların birçoğunun eş dost vasıtası ile ve tanıdık referansı ile hizmet sektöründe, kayıt dışı bakım ve temizlik gibi işlerde çalıştıkları gözlenmiştir.

"Tütünden sonra sigortalı iş aradım. Tahsilim yoktu bulamadım. Bir süre evde öyle durdum ev hanımı oldum. Sonra boşandım. Mecbur bir işe ihtiyacım vardı çocuk bakmaya başladım. Tahsilim olmadı̆̆ için sigortalı bir iş bulamadım. Eş dost tanıdık yönlendirdi şimdi bir tanıdığın çocuğuna kendi evimde bakıyorum.”(K.2)

“Tütünü bırakıp şehre gelince bir sosyal güvencem olsun para kazanayım istedim... Önce bir kafede çalışmaya başladım. Sonra okulun hizmetli alacağını duydum. Tanıdıkların vesilesi ile başvuru formu doldurdum verdim. Sonra işe alındım ve başladım.” (K.3)

"Tütünden sonra iş aradım. Ne iş olursa yapmaya çalışacaktım. Önce çok aradım. Sonra birisi aracılığıyla, tavsiye üzerine çocuk bakmaya başladım.”(K.5)

Tütün sektörünün özelde Muğla ilinde güç kaybetmesi ve istihdam yaratma kabiliyetini kaybetmesi üzerine tütünde çalışan birçok kadının şu an nasıl bir tablo ile karşı karşıya kaldıklarını ortaya çıkartmak adına görüşme yapılan kadınlara, "çevrelerinde eskiden tütünde çalışan kadınların 
şu an ne yaptıklarını" sorulmuştur. Alınan yanıtlarda eskiden tütünde çalışan kadınların bugün çalışma hayatından ayrılmış, tarım sektöründe ücretsiz aile işçisi olarak çalışmaya devam etmiş, kayıt dışı sektörlere kaymış ya da başta hizmet sektörü olmak üzere başka sektörlerde istihdam edilmiş oldukları tespit edilmiştir.

"Daha önce tütünde çalışanların bir kısmı şu anda çalışmıyor. Onlarda benim gibi ev hanımı. Bazıları Marmaris'te otellerde iş buldu temizlikçi, bulaşıkçı olarak çalışıyor. Bazıları evlere temizliğe gidiyor. Bir iki kadın da çocuk bakıcılığı yapıyor.”(K.1)

"Yevmiyeli tarımda çalışanlar var. Eve gündelikçiliğe giden var, çocuk bakan var. Kocası iyi kazandığı için çalışmayan da var."(K.3)

“Kimisi otellerde çalışmaya başladı, kimisi Muğla Merkez'de çocuk bakmaya veya evlerde temizlik yapmaya gitti. Göç eden yok."(K.4)

"Gençler iş bulup çalışıyor. Çocuk bakma, IŞKUR aracılı̆̆ıyla bir yere yerleşme, hastane, kantin gibi yerlerde iş bulanlar oldu. Yaşllar ise evde vazgeçtiler."(K.5)

Tütün sektöründe çalışan kadınların kendi hesabına ya da ücretsiz aile işçisi olarak mı yoksa başkalarının tütün tarlalarında işçi olarak $\mathrm{m}$ çalıştıkları da tütünde çalışan kadınların istihdam edilme durumlarını yorumlamak adına önemli bir konudur. $\mathrm{Bu}$ nedenle görüşme yapılan kadınlara bu durumu tespit etmeye yönelik sorular yöneltilmiştir. Alınan cevaplar kadınların genellikle ücretsiz aile işçisi olarak çalıştıklarını ve ayrıca imece usulünün farklı bir boyutu olarak bildikleri iş olması sebebiyle başkalarının tarlalarında da çalıştıklarını ortaya koymaktadır.

"Tütünde hem kendi adıma kendi bahçemde tütün yapıp sattım hem de daha önce başkalarına işçi olarak gittim."(K.1)

"Babamın evindeyken kendi bahçelerimizi tütün dikiyorduk kendi işimizin iş̧̧isiydik. Sonra başkalarının tütününe işçi olarak gittim.” (K.2)

"Kendi adıma çalıştım. Cüzdan çıkartılıyor, kooperatif kredi veriyor, cüzdan kimin üstüne ise krediden o faydalantyor, ona veriyorduk. Tarlay kiralıyordum. Çift para, tarla da kira yani." (K.5)

“Biz tütünü kendi adımıza yapardık yalnız tarlaları kiralıyorduk. Buranın tarlaları zaten Muğla'nın zenginlerinin tarlalartydı. Bizim Kötekli köyü bütü̈n tarlaları kiralayarak tütün yaparlardl."(K.6)

Tütün sektörü daha önce de ifade edildiği gibi eski dönemlerde Muğla ilinin önemli gelir kaynaklarından birini oluşturmaktaydı. Kadınların çoğu bu sektörde istihdam edilmekte ve refah seviyelerini etkileyecek düzeyde gelirler elde etmekteydiler. Tütün sektörünün artık önemli bir gelir kaynağı olmadığı ve hatta Muğla ilinde tütün yapanların neredeyse kalmadığı için görüşme yapılan kadınlara tütünde çalıştıkları dönem ile bugünler arasındaki farklar ve bu farkların hayatlarına olan etkileri sorulmuştur. Verilen cevaplar neticesinde ciddi bir gelir kaybı yaşandığı, bunun sonucunda da yoksullaşmanın arttığı tespit edilmiştir.

"Tütün eskilerden bizim en önemli gelir kapımızd. Bununla geçinirdik ben oturduğum bu evi tütünden kazandığım para ile yaptırdım... Yoksulluk ve refah kaybı elbette yaşıyoruz. Tütün ölmese köyümüz beldemiz biz daha zengin yaşayabilirdik.” (K.1)

“Tütüncülü̈̆̈̈ bırakan insanların hepsi günü kurtarmanın peşinde, öyle çok güzel bir yaşantıları yok, bugün çok şükür karnımı doyurdum yarına Allah kerim diyen insanlar.” (K.8)

Daha önce tütünde çalışan kadınlara, çalışma koşulları ve süreleri ile ilgili tütünden önceki ve sonraki dönemi kıyaslamak için sorular sorulmuştur. Alınan cevaplar neticesinde; tütün sektöründe çalıştıkları dönemle sonraki dönem arasında farklı çalışma koşullarının olduğu, 
bazılarının tütün öncesi daha makul çalışma şartlarına sahip olduğu, bazılarının ise tütün sonrası daha makul çalışma şartlarına sahip olduğu gözlenmiştir.

“Çalışma sürelerimiz tütünde 4-5 ay çalışıyorduk toplu para alıyorduk. Sonra başka işler yapıyorduk halı dokuyorduk bahçe yapıyorduk. Şimdi daha çok çalışıoruz ama daha az kazanyyoruz. Tütün zahmetli zordu ama bereketli ve çok kazançlydl. Şimdi asgari ücretle haftada 6 gün çalışıyoruz.” (K.3)

"Tütünde nerdeyse tüm gün çalışıyorduk. Gece 2 kalkıp öğleden sonra 5-6 ya kadar çalıştı̆̆ımız oluyordu. Şimdi sabah 8 de çocuk geliyor akşam 6 gibi çocuğu altyorlar. Haftada 5 gün bu kadar çalışıyorum. Çalışma sürem elbette azald. Hem de evimde kendi işlerime bakarken çocuk baklyorum tabi ki daha rahatım. Ama geçinmekte zorlantyorum.”(K.2)

Tütün sektörüne devlet tarafından doğrudan ya da dolaylı olarak yapılan destekler hakkında katılımcılara sorular sorulmuştur. Alınan cevaplar doğrultusunda katılımcılardan bazılarının, doğrudan alım desteği, üretim girdisi desteği vb. desteklerin devlet tarafından yapıldığını bazılarının ise tütün ile ilgili devlet tarafından herhangi bir doğrudan ya da dolaylı desteğin olmadığını ifade ettikleri görülmüştür.

“Babam tütün yaparken devletten mazot parası alırdı. Ürettiğimiz kesin belli fiyattan satılırdı. Satabilecek miyiz kaça satarı gibi düşünmez ürettiğimizin karşılığını alırdık. Sonraları başkasının hesabına işçi olarak çalışstığım için bu konuları çok bilmiyorum. Ama destek olsalardı tütün bu bölgede bitmezdi halk bundan ekmek yiyordu. Bizim buralarda herkes neredeyse bir zamanlı̆̆ına tütünde çalışmıştır. Herkesin ekmek kapısı kapandı.”(K.2)

"Tütün bir dönem devlet tarafindan alınıyordu işse o zaman garanti sattyorduk hem de yüksek fiyata satıyorduk. İşte o zamanlar tütün yapmak karlyydl.” (K.3)

“Kooperatiften para veriliyordu. Bu paralar önden veriliyor masraflar için. Masraflar; tarla kirası, fidan parası, dikme makinesi ile diktirme parası. Kooperatif bunları dönem sonunda senden hep kesiyordu. 10 dönüm yapanlar daha çok masraf ama daha çok da kazanç elde ettiler."(K.5)

"Bizim zamanımıda biz tütünde hiç destek görmedik... Başka yerlere verdiyse devlet bilmem ama bizim bu Yerkesik için hiçbir ödenek olmadr... Şuanda tütün yok ki ne ödeneği olsun... Olanlarda şimdi varsa duyduğumuza göre şirketlere yapıyormuş balya yokmuş kağıt kutuya sartyorlarmış. (K.9)

Araştırmada katılımcılara Muğla özelinde tütüncülük faaliyetlerinin bu noktaya gelmesinde etkili olan unsurları yorumlamaları istenmiştir. Alınan cevaplarda; yukarıda değinilen tarım politikalarında yaşanan değişim ve dönüşümün yaratmış olduğu değişkenlerin tütüncülük faaliyetinin değer kaybetmesinde etkili olduğu görülmüsşür.

“Tütüne destek yetersiz. Tütün alım garantisi ve TEKEL'in özelleşmesi büyük üretici ile karşı karşıya getirdi. Fiyat kontrolleri onların elinde, vatandaşın bir hakkı olmuyor. Eskiden tütünün kilosu, büyük rakı şişesiyle başa başmış. Şimdi ise tütünnün kilosu çok ucuza gidiyor. Karlar azald. Tütün rehberleri, tütün tüccarl, tekel alırdı. Kim fazla verirse vaktinde verirse (ödeme yaparsa), ona tütün teslim edilir, anlaşma yapılırdı.”(K.5)

"Tütünde gelinen bu durumun sebepleri, firmaların rant peşinde olmaları bizim TEKEL 'in kapatılması en önemli nedeni, doğrudan alım yapıyor ve üreticiyi hiçbir zaman mağdur etmiyordu... Desteklemesini de çok güzel veriyordu... Bence en önemli sebep TEKEL'in kapatılması diğer özel sektör firmalarının bu işi eline alması olarak görüyorum... TEKEL kapanınca rekabet olmayınca her şey firmaların keyfine kaldı, aynı özel iş̧̧iler gibi ki insanlar üç kuruş ekmek parasının peşinde tamam diyorlar yeter ki üç kuruş ver biz bu kotaya razıyız emeklerini hiç görmüyorlar sadece alacakları parayı görüyorlar” (K.8) 
"Tütünün bu duruma gelmesinin nedeni kota koydular balyaları 50-55 kilodan fazla olmasın dediler... Sonrada birer liradan fiyat biçtiler... Önceden bir liraya verilmezdi daha üstünde verilirdi tabi ettiğıimiz emeğin karşılığını alamayınca baktık çok zarardayız ondan sonra bizde biraktık... TEKEL'in kapanmasının da etkisi oldu... Herkes devlet kaptsi diye TEKEL'e vermek isterdi... Tüccar ondan beş kuruş on kuruş yirmi kuruş geçerdi ama ille TEKEL'e verilirdi TEKEL devlet malı olduğu için garanti olduğu için tüccar riskli ondan hep TEKEL'e verilirdi... TEKEL olunca ne zaman alıp ne zaman vereceğin belliydi baharın parant alırdın... Alacaklarımızı ona göre alırdık tüccarlarda ihtiyaçlarımızı verirdi yăg alırdık tüccar verirdi nasıl olsa tütün parası alacak öder diye, hadi şimdi git de marketten al bakalım bir kilo yă̆ı sana veriyorlar mı veresiye şimdi çırt çırt kağıt... TEKEL kapandıktan sonra emek çok ekmek yok ama parası yine TEKEL kapanana kadar iyiydi bedellikten başka bir şeysi olmadı... Sapı elimizde kaldt... (K.9)

Yukarıda belirtilen yorumlar 1şığında bugün gelinen noktada tütüncülük faaliyetlerinde olumsuz bir tablonun görünüyor olmasının ardındaki değişkenlerin başında tarım politikaları bağlamında tarım sektöründe uygulanan programların etkili olduğu söylenebilir.

\section{Sonuç}

Neo-klasik ekonomi yaklaşımı özünde dengeli bir büyüme sürecinden bahseder. Bu süreçte ekonomideki sektörler de zamanla ağırlıklarını değiştirirler. İlk değişim tarım sektöründe beklenir ve bu da tarım sektörünün ağırlığının azalması anlamına gelmektedir. Özellikle tarımsal gelir, tarımsal yatırımlar ve tarımsal dış ticaret payları azalırken sektördeki istihdam oranı da azalır. Buradaki azalma sanayi ve hizmetler sektörüne zorunlu geçişi gerekli kılmaktadır. Ancak Türkiye özelinde uygulanan tarım politikaları beklenen bu değişimi gerçekleştirmek noktasında yeterli olmamış, ilerleyen süreç içerisinde gerek tarımsal üretimde gerekse üretici sayısında ciddi azalmalar yaşanmıştır. Beraberinde yaşanan kırdan kente göçle birlikte önemli sosyo-ekonomik sorunların yaşanması da kaçınılmaz olmuştur.

Tarım sektörünün genelinde yaşanan bu sorunlar tarım sektörünün bir alt faaliyet alanı olan tütüncülük faaliyetlerinde de kendini göstermiştir. Özellikle Neo-liberal ekonomi politikaları çerçevesinde 1990'lı yılların başlarına kadar Muğla ilinde yüksek seviyelerde olan tütün üretimi, uygulamaya alınan tarım politikaları ve programları kapsamında (kota uygulaması, tekelin kapatılması, özelleştirme, garanti alım gibi desteklerin dönüşüme uğraması neticesinde) düşüşe geçmiştir.

1993 yılında Bakanlar Kurulu kararıyla başlayan kota uygulamasıyla ve 2002 yılında da sözleşmeli üretime geçilmesi ile tütün üreticisi ve tütün üretimi olumsuz etkilenmiştir. Ayrıca, ortaya çıkan olumsuz tablonun oluşmasında düşük fiyat politikaları ve ülkemizde yaşanan ekonomik krizler de etkili olmuştur. Bunların sonucunda tütün sektörü cazibesini yitirmiş, değer kaybetmiş ve tütüncülük faaliyetleri her geçen gün giderek azalmıştır. Doğal olarak bu sektörde istihdam edilenlerde bu olumsuz tablodan etkilenmiş ve yaşanan değişimler sonucunda işgücü piyasasının yapısını da sektörler arası geçiş bağlamında dönüşüme uğratmıştır.

Yoğun olarak tütüncülük faaliyetlerinde istihdam edilen kadınlar ise tütüncülüğün sekteye uğraması sonucu tarımdan hizmet sektörüne geçmiş, kayıt dışı işlerde çalışmaya başlamış ya da çalışma hayatının dışında kalmıştır. Ayrıca daha önce tütünde çalışan kadınların günümüzde yaşam standartları incelendiğinde ise refah seviyelerinde düşüş yaşadıkları da elde edilen bulgular arasındadir.

Tarım sektöründe ve tütünde gelinen bu noktada tarım sektöründeki destekleme politikalarındaki değişimler ve üreticilerin gelecekteki beklentilerinin olumsuz yönde değişmesi olumsuz yönde etkili olmuştur. Tarımsal üretim faktörü sahiplerinin bugünkü durumu; üretirken hizmet edene dönüşen bir işgücünün varlığını doğrulamıştır. 


\section{Kaynakça}

Aydın, S. ve Erdal, Y. S. (2018). “Antropoloji”, T.C. Anadolu Üniversitesi Açı Öğretim Fakültesi Yayını, Yayın No.:1761.

Boratav, K. (2003), “Türkiye İktisat Tarihi 1908-2002”, 7.Baskı, İmge Kitabevi.

Çevik, D. (2017), “Türkiye'nin Tarım Politikası ve Tarımda Yaşanan Temel Sorunlar”, http://www.alomaliye.com/2017/05/22/tarim-politikasi-ve-tarimda-yasanan-sorunlar/ (Erişim Tarihi: 20 Aralık 2018)

Çondur, F. ve Bölükbaş, M. (2014), “Türkiye'de İşgücü Piyasası ve Genç İşsizlik- Büyüme İlişkisi Üzerine Bir İnceleme”, Amme İdaresi Dergisi, 47(2), 77-93.

Eğilmez, M. ve Kumcu Ercan (2018), "Ekonomi Politikası, Teori ve Türkiye Uygulaması", 24. Baskı, Remzi Kitabevi.

Elliott, R. F. (1990), “Labor Economics: A Comparative Text”, McGraw-Hill College

Eren, A. (2000), “Türkiye'nin Ekonomik Yapısı ve Güncel Sorunlar”, Muğla Üniversitesi Yayını, IV. Bask1.

Gönel, F. D. (2013), "Kalkınma Ekonomisi”, 2. Bask1, Efil Yayınevi.

Günaydın, G. (2010), “Tarım ve Kırsallıkta Dönüşüm”, Tan Kitabevi.

Harvey, D. (1993), “Esneklik: Tehdit mi Yoksa Fırsat mı?”, Toplum ve Bilim Dergisi, Sayı 56-61 Bahar, 83-92.

İlhan, S. (2007), "Yeni Kapitalizmin Karanlık Yüzü: İnsanilik ve Ahlâkilik Söylemlerinin Sahiciliği Üzerine”, Frrat Üniversitesi Sosyal Bilimler Dergisi,17 (2), 283-306.

Karataş, A. (2015). "İstanbul'da Bankacılık Sektöründe Cinsiyete Dayalı Kariyer Ve Ücret Açığı". T.C. Muğla Sitkı Koçman Üniversitesi, Sosyal Bilimler Enstitüsü İktisat Anabilim Dalı, Doktora Tezi.

Kitzinger, J. (1995). “Qualitative Research: Introducing Focus Groups”, BMJ, 311.

Minibaş, T. (1994), “Çağ Atlatma Serüveni”, Birinci Basım, Bağlam Yayıncılık.

Önder, N. (2013), “Türkiye’de Kadın İşü̈cünün Görünümü”, ÇSGB Çalışma Dünyası Dergisi, 1, 1 35-61.

TÜIKK (2018), http://www.tuik.gov.tr/PreTabloArama.do?metod=search\&araType=vt (Erişim Tarihi: 20 Aralık 2018) 